\title{
Efficacy assessment of selected fungicides in the control of wet bubble (Mycogone perniciosa) in white button mushroom (Agaricus bisporus)
}

\author{
Ocena skuteczności wybranych fungicydów w ochronie pieczarki \\ (Agaricus bisporus) przed białą zgnilizną (Mycogone perniciosa)
}

\author{
Joanna Szumigaj-Tarnowska*, Zbigniew Uliński, Czesław Ślusarski
}

\begin{abstract}
Summary
Mycogone perniciosa is the fungal pathogen causing the wet bubble of white button mushroom (Agaricus bisporus). The main symptoms of disease are undifferentiated forms of mushroom tissue, cap spotting and development of amber liquid droplets on the distorted mushrooms. There is only one fungicide based on prochloraz-Mn available for the control of fungal diseases of white button mushroom. The aim of the study was to assess the effectiveness of chemical products such as prochloraz-Mn and imazalil, and natural fungicides obtained from plants (grapefruit extract and tea tree extract) in the control of wet bubble. The inoculum of $M$. perniciosa at different concentrations of spores was applied to the casing and then fungicide was added. The effectiveness of examined products was assessed on the basis of mushroom yield and severity of disease symptoms in the first and the second flushes. The products based on imazalil showed a high effectiveness, comparable with prochloraz-Mn efficacy, in both flushes at conidia concentration of $1.3 \times 10^{4}$ and $13 \times 10^{6}$ per $\mathrm{m}^{2}$ of casing. The natural fungicide based on a grapefruit extract was effective in reducing the wet bubble in the first flush, at conidia concentration of $1.3 \times 10^{4}$ per $\mathrm{m}^{2}$ of casing soil.
\end{abstract}

Key words: wet bubble; Mycogone perniciosa; Agaricus bisporus; control; natural plant protection products

\begin{abstract}
Streszczenie
Mycogone perniciosa, grzyb patogeniczny, wywołuje białą zgniliznę pieczarki dwuzarodnikowej (Agaricus bisporus). Choroba objawia się powstawaniem dużych, nieregularnych, nabrzmiałych tworów z tkanki pieczarki, a także rozwojem bursztynowej zawiesiny na porażonych grzybach. Obecnie w ochronie pieczarki przed chorobami grzybowymi dostępny jest jeden preparat zawierający prochloraz-Mn. Celem badań była ocena skuteczności środków chemicznych (prochloraz-Mn oraz imazalil) i naturalnych z ekstraktów roślinnych (ekstrakt z grejpfruta oraz drzewa herbacianego) w ochronie pieczarki przed białą zgnilizną. Badania polegały na zainfekowaniu uprawy pieczarki zawiesiną makrokonidiów izolatów grzyba $M$. perniciosa o różnej koncentracji, a następnie zastosowaniu fungicydów. Skuteczność preparatów oceniano na podstawie zebranego plonu owocników, a także stopnia porażenia uprawy w pierwszym i drugim rzucie. Preparat zawierający imazalil wykazał wysoką skuteczność, porównywalną do prochlorazu-Mn, w I i II rzucie przy zainfekowaniu uprawy zarodnikami w liczbie $1,3 \times 10^{4}$ i 1,3 $310^{6}$ na $\mathrm{m}^{2}$ okrywy. Preparat z ekstraktu grejpfruta skutecznie ograniczył chorobę $w$ I rzucie przy koncentracji zarodników $1,3 \times 10^{4}$ na $\mathrm{m}^{2}$ okrywy.
\end{abstract}

Słowa kluczowe: biała zgnilizna; Mycogone perniciosa; Agaricus bisporus; ochrona; naturalne preparaty roślinne

Instytut Ogrodnictwa

Samodzielna Pracownia Grzybów Uprawnych

Konstytucji 3 Maja 1/3, 96-100 Skierniewice

*corresponding author: joanna.tarnowska@inhort.pl 


\section{Wstęp / Introduction}

Uprawa pieczarki dwuzarodnikowej (Agaricus bispo$r u s)$ jako typowa monokultura jest narażona na infekcje pochodzenia grzybowego oraz bakteryjnego. Jedną z częściej pojawiających się chorób grzybowych jest biała zgnilizna wywoływana przez Mycogone perniciosa (Magn.) Delacr. Porażenie uprawy przez tego patogena może prowadzić do utraty $15-30 \%$ plonu, zwłaszcza jeśli wystąpi w pierwszym rzucie owocników. Objawami choroby są duże, zdeformowane twory, utworzone $\mathrm{z}$ tkanki pieczarki. Często porażeniu towarzyszy bursztynowa wydzielina, będąca pożywką dla bakterii, co w efekcie jest przyczyną szybkiego gnicia porażonych grzybów. Porażenie dorosłych owocników jest przyczyną powstawania grzybów o rozdętych trzonach i zniekształconych kapeluszach (Fletcher i wsp. 1975). Objawy chorobowe pojawiające się w pierwszym rzucie pieczarek wskazują, że źródłem porażenia jest źle zdezynfekowana okrywa lub zakażenie mogło wystąpić w trakcie jej nakładania. Porażenie pieczarek w kolejnych rzutach sugeruje wtórne zakażenie uprawy, np. przez wniesienie zarodników grzyba $\mathrm{z}$ prądem powietrza, na ubraniach pracowników czy narzędziach (Ślusarski i wsp. 2012a). Obecnie do ochrony pieczarki przed chorobami grzybowymi jest zarejestrowany jeden preparat, zawierający jako substancję czynną prochloraz z manganem (Gea i wsp. 2010) Wprowadzenie do kalendarza ochrony pieczarki nowych preparatów musi być poprzedzone wieloma badaniami oceny skuteczności środków w ograniczaniu infekcji grzybowych.

Celem badań była ocena skuteczności środków chemicznych (zawierających prochloraz-Mn i imazalil) oraz naturalnych z ekstraktami roślinnymi (z grejpfruta i z drzewa herbacianego) w ochronie pieczarki przez białą zgnilizną.

\section{Materiały i metody / Materials and methods}

Skuteczność fungicydów (tab. 1) w zwalczaniu białej zgnilizny pieczarki badano w warunkach uprawowych w klimatyzowanych halach. Doświadczenie prowadzono w doniczkach wypełnionych podłożem III fazy przerośniętym grzybnią pieczarki A15 w ilości $1,7 \mathrm{~kg}$ i ziemią okrywową o grubości $4 \mathrm{~cm}$ (pole powierzchni okrywy wynosiło $0,038 \mathrm{~m}^{2}$ ). W czasie przerostu okrywy grzybnią pieczarki $\mathrm{W}$ hali zapewniono temperaturę $22-23^{\circ} \mathrm{C}$, stężenie dwutlenku węgla na poziomie 3000 ppm i względną wilgotność powietrza 92-95\%. Doświadczenie założono dwukrotnie jako dwuczynnikowe w czterech powtórzeniach. Czynnik pierwszy stanowiły stężenia makrokonidiów, a drugi badane fungicydy. Po nałożeniu okrywy uprawę sztucznie zainfekowano zawiesiną o koncentracji makrokonidiów $M$. perniciosa $1 \times 10^{2} / \mathrm{ml} \mathrm{i} 10^{4} / \mathrm{ml}$, w ilości warunkującej uzyskanie około $1,3 \times 10^{4}$ i 1,3 $\times 10^{6}$ konidiów na $\mathrm{m}^{2}$ okrywy. Izolat grzyba patogenicznego uzyskano $\mathrm{W} 2011$ roku $\mathrm{z}$ porażonego owocnika pieczarki pochodzącego $\mathrm{z}$ pieczarkarni $\mathrm{W}$ rejonie mazowieckim. Izolat patogena przechowywano $\mathrm{w} 10 \%$ roztworze glicerolu w temperaturze $-80^{\circ} \mathrm{C}$. Do badań grzyb był przeszczepiany na świeżą pożywkę agarową PDA (Potato Dextrose Agar). Przynależność gatunkową patogena określono na podstawie obserwacji mikroskopowych (badano morfologię konidioforów i zarodników), przeprowadzono również charakterystykę wzrostu na różnych pożywkach mikrobiologicznych, a nasteppnie wykonano identyfikację molekularną wykorzystując metodę PCR (polymeraze chain reaction) i sekwencjonowanie regionu ITS rDNA. Jako izolaty referencyjne wykorzystano dwa izolaty Hypomyces perniciosus CBS 322.52 i CBS 815.73 z holenderskiej kolekcji grzybów Centraalbureau voor Schimmelcultures (CBS) (Szumigaj-Tarnowska i wsp. 2013). Badane środki zastosowano $\mathrm{w}$ dawkach rekomendowanych przez producentów, które podano w tabeli 1. Dawka cieczy użytkowej wynosiła $1 \mathrm{l} / \mathrm{m}^{2}$. Próby kontrolne podlewano wodą. W pozostałych dniach, aż do rozpoczęcia szoku, tj. zmiany parametrów mikroklimatu $\mathrm{w}$ hali uprawowej, uprawę codziennie podlewano woda w ilości 1,51 na $\mathrm{m}^{2}$ okrywy.

Skuteczność badanych fungicydów określano na podstawie plonu zebranego z próby kontrolnej i prób zakażanych. Wyniki poddano analizie wariancji dla doświadczeń dwuczynnikowych. Do oceny różnic między średnimi wykorzystano test Tukeya przy poziomie istotności $\mathrm{p}=0,05$. Ponadto określano stopień rozwoju choroby na podstawie 5-stopniowej skali 0-4, gdzie: 0 - brak objawów chorobowych, 1 - pojedyncze owocniki z objawami choroby, 2 - 10-40\% uprawy porażonej, $3-41-70 \%$ uprawy porażonej, $4-71-100 \%$ uprawy porażonej.

Tabela 1. Charakterystyka testowanych preparatów i stężenia stosowane w badaniach

Table 1. Characterization of tested products and concentrations used in the experiments

\begin{tabular}{l|c|c|c}
\hline $\begin{array}{c}\text { Preparat } \\
\text { Product }\end{array}$ & $\begin{array}{c}\text { Substancja czynna } \\
\text { Active substance }\end{array}$ & $\begin{array}{c}\text { Zawartość substancji aktywnej } \\
\text { Content of active substance } \\
{[\mathrm{g} / \mathrm{l}]}\end{array}$ & $\begin{array}{c}\text { Stosowane stężenia } \\
\text { Used concentration }\end{array}$ \\
\hline Sporgon 50 WP & $\begin{array}{c}\text { prochloraz-manganese } \\
\text { (prochloraz-Mn) }\end{array}$ & 500 & $3 \mathrm{~g} / \mathrm{l} / \mathrm{m}^{2}$ \\
\hline Fungazil 100 SL & imazalil & 100 & $6 \mathrm{ml} / 1 / \mathrm{m}^{2}$ \\
\hline Grevit 200 SL & grapefruit extract & 200 & $20 \mathrm{ml} / 1 / \mathrm{m}^{2}$ \\
\hline Timorex Gold 24 EC & tea tree extract & 240 & $2 \mathrm{ml} / 1 / \mathrm{m}^{2}$ \\
\hline
\end{tabular}




\section{Wyniki i dyskusja / Results and discussion}

Lustrację uprawy pieczarki w celu określenia terminu pojawienia się objawów choroby oraz stopnia porażenia uprawy przez białą zgniliznę prowadzono po 14, 19 i 25 dniach od zainfekowania uprawy zarodnikami M. perniciosa (tab. 2). Zainfekowanie uprawy konidiami w liczbie $1,3 \times 10^{4} / \mathrm{m}^{2}$ wywołało pierwsze objawy chorobowe w trakcie trwania I rzutu, po 19 dniach od zainfekowania. W kombinacji kontrolnej bez fungicydów oraz potraktowanej ekstraktami roślinnymi obserwowano niewielką liczbę porażonych owocników, natomiast w trakcie trwania II rzutu $100 \%$ powierzchni tych upraw było zainfekowane przez patogena. W uprawach ze środkami chemicznymi objawy chorobowe (zdeformowane pojedyncze owocniki) pojawiły się dopiero w II rzucie, po 25 dniach od zainfekowania uprawy (tab. 2). Zainfekowanie uprawy liczbą zarodników $1,3 \times 10^{6} / \mathrm{m}^{2}$ wywołało wyraźne objawy chorobowe $\mathrm{w}$ próbach kontrolnych zakażanych (bez środków) i potraktowanych ekstraktami roślinnymi już po 14 dniach od infekcji, tj. przed I rzutem (porażone od 40 do 50\% powierzchni upraw). Całkowite porażenie uprawy w tych kombinacjach obserwowano w trakcie trwania I rzutu, po 19 dniach od zainfekowania. W kombinacjach ze środkami chemicznymi (prochloraz-Mn i imazalil) pojedyncze owocniki $\mathrm{z}$ objawami choroby stwierdzono po 19 dniach od zainfekowania, natomiast po 25 dniach porażeniu uległo $50-60 \%$ powierzchni tych upraw. Znacznie szybciej objawy chorobowe wywołane przez M. perniciosa uzyskała Potoćnik i wsp. (2008) oraz Kouser i Shah (2013), bo po 7-8 dniach od zainfekowania okrywy, przy czym inokulum wykorzystane w doświadczeniach wynosiło $10^{6}$ zarodników/ml. Według badań Fletcher i wsp. (1995) szybkość i nasilenie objawów białej zgnilizny może zależeć także od izolatu $M$. perniciosa, czym można tłumaczyć różnice $\mathrm{w}$ terminie pojawiania się objawów choroby w prezentowanych i cytowanych badaniach.

Wyniki plonu owocników wskazują, że zainfekowanie uprawy zarodnikami $M$. perniciosa w liczbie $1,3 \times 10^{4} / \mathrm{m}^{2}$ powoduje istotny ubytek plonu, zarówno w rzucie I (tab. 3, 5), jak i w II (tab. 4, 6). W próbach kontrolnych bez dodatku preparatów średni procentowy ubytek plonu wyniósł 40\% i 50\%, odpowiednio w I i II rzucie (rys. 1, 2). Plon w kombinacjach, do których dodano preparaty roślinne był porównywalny do plonu uzyskanego w kontroli zakażanej bez fungicydu, co wskazywało na słabe ograniczenie rozwoju białej zgnilizny przez te środki (tab. 3-6). Wyjątek stanowiła próba $\mathrm{z}$ ekstraktem grejpfruta $\mathrm{w}$ doświadczeniu I, w której plon w I rzucie był znacznie wyższy niż w kombinacji z ekstraktem z drzewa herbacianego, a porównywalny $\mathrm{z}$ plonem uzyskanym w kombinacji z imazalilem (tab. 3). Procentowy ubytek plonu w kombinacjach z preparatami roślinnymi w I rzucie wynosił około 25 i 15\% oraz w II rzucie - 45 i 50\%, odpowiednio dla ekstraktu $\mathrm{z}$ drzewa herbacianego i grejpfruta (rys. 1, 2).

Zastosowanie preparatów chemicznych w uprawie wpłynęło na wysoki plon owocników w obu doświadczeniach, zarówno w rzucie I, jak i w II. Ubytek plonu w I rzucie w tych kombinacjach wynosił 5\% (prochlorazMn) i 20\% (imazalil) oraz 5\% dla obu preparatów w II rzucie (rys. 1, 2).

W wyniku zainfekowania uprawy zarodnikami w ilości $1,3 \times 10^{6} / \mathrm{m}^{2} \mathrm{w}$ wariantach bez fungicydu oraz $\mathrm{z}$ dodatkiem środków roślinnych w I rzucie plonu nie uzyskano (doświadczenie I), bądź plon ten był istotnie niższy niż w próbach, w których zastosowano preparaty chemiczne (doświadczenie II). W kombinacjach, które traktowano środkami chemicznymi uzyskiwano plon rzędu $200 \mathrm{~g} / 0,038 \mathrm{~m}^{2} \mathrm{w}$ obu doświadczeniach, natomiast $\mathrm{w}$ próbach $\mathrm{z}$ ekstraktami roślinnymi plon w II doświadczeniu

Tabela 2. Charakterystyka i skala porażenia uprawy pieczarki w zależności od koncentracji konidiów M. perniciosa i zastosowanego fungicydu

Table 2. Characterization and infection scale of white button mushroom crops depending on the concentration of M. perniciosa conidia and used fungicide

\begin{tabular}{|c|c|c|c|c|c|c|}
\hline \multirow[t]{2}{*}{$\begin{array}{c}\text { Wariant } \\
\text { Treatments }\end{array}$} & \multicolumn{2}{|c|}{$\begin{array}{l}\text { Przed I rzutem }-14 \text { dni } \\
\text { po zainfekowaniu } \\
\text { Before first flush }-14 \text { days } \\
\text { after infection }\end{array}$} & \multicolumn{2}{|c|}{$\begin{array}{c}\text { I rzut }-19 \text { dni } \\
\text { po zainfekowaniu } \\
\text { First flush }-19 \text { days } \\
\text { after infection }\end{array}$} & \multicolumn{2}{|c|}{$\begin{array}{c}\text { II rzut }-25 \text { dni } \\
\text { po zainfekowaniu } \\
\text { Second flush }-25 \text { days } \\
\text { after infection }\end{array}$} \\
\hline & $1,3 \times 10^{4} / \mathrm{m}^{2}$ & $1,3 \times 10^{6} / \mathrm{m}^{2}$ & $1,3 \times 10^{4} / \mathrm{m}^{2}$ & $1,3 \times 10^{6} / \mathrm{m}^{2}$ & $1,3 \times 10^{4} / \mathrm{m}^{2}$ & $1,3 \times 10^{6} / \mathrm{m}^{2}$ \\
\hline $\begin{array}{l}\text { Bez fungicydu } \\
\text { Without fungicide }\end{array}$ & 0 & $3-60 \%$ & 1 & $4-100 \%$ & $4-80 \%$ & $4-100 \%$ \\
\hline Prochloraz-Mn & 0 & 0 & 0 & 1 & 1 & $3-50 \%$ \\
\hline Imazalil & 0 & 0 & 0 & 1 & 1 & $3-60 \%$ \\
\hline $\begin{array}{l}\text { Ekstrakt } \mathrm{z} \text { drzewa herbacianego } \\
\text { Tea tree extract }\end{array}$ & 0 & $3-50 \%$ & 1 & $4-100 \%$ & $3-70 \%$ & $4-100 \%$ \\
\hline $\begin{array}{l}\text { Ekstrakt z grejpfruta } \\
\text { Grapefruit extract }\end{array}$ & 0 & $2-40 \%$ & 1 & $4-80 \%$ & $3-70 \%$ & $4-100 \%$ \\
\hline
\end{tabular}

0 - brak objawów chorobowych - no disease symptoms

1 - pojedyncze owocniki z objawami chorób - single sporophores with disease symptoms

$2-10-40 \%$ uprawy porażonej $-10-40 \%$ of infected crop

$3-41-70 \%$ uprawy porażonej $-41-70 \%$ of infected crop

$4-71-100 \%$ uprawy porażonej $-71-100 \%$ of infected crop 
Tabela 3. Plon owocników w pierwszym rzucie po porażeniu przez M. perniciosa w zależności od zastosowanego fungicydu $\left[\mathrm{g} / 0,038 \mathrm{~m}^{2}\right]$ - doświadczenie I

Table 3. Mushroom yield in the first flush after infection with M. perniciosa depending on used fungicide $\left[\mathrm{g} / 0.038 \mathrm{~m}^{2}\right]-$ Experiment I

\begin{tabular}{|c|c|c|c|c|}
\hline \multirow{2}{*}{$\begin{array}{l}\text { Wariant } \\
\text { Treatment }\end{array}$} & \multicolumn{3}{|c|}{$\begin{array}{l}\text { Liczba zarodników } / \mathrm{m}^{2} \text { okrywy } \\
\text { Number of conidia } / \mathrm{m}^{2} \text { casing }\end{array}$} & \multirow{2}{*}{$\begin{array}{l}\text { Średnia } \\
\text { Mean }\end{array}$} \\
\hline & 0 & $1,3 \times 10^{6} / \mathrm{m}^{2}$ & $1,3 \times 10^{6} / \mathrm{m}^{2}$ & \\
\hline $\begin{array}{l}\text { Bez fungicydu } \\
\text { Without fungicide }\end{array}$ & $408,7^{* * *}$ & 254,9 & 0,0 & $221,2 \mathrm{c}^{* *}$ \\
\hline Prochloraz-Mn & 403,2 & 377,2 & 240,9 & 340,4 a \\
\hline Imazalil & 420,9 & 310,5 & 202,7 & $311,4 \mathrm{ab}$ \\
\hline $\begin{array}{l}\text { Ekstrakt } \mathrm{z} \text { drzewa herbacianego } \\
\text { Tea tree extract }\end{array}$ & 409,6 & 258,9 & 0,0 & $222,8 \mathrm{c}$ \\
\hline $\begin{array}{l}\text { Ekstrakt } \mathrm{z} \text { grejpfruta } \\
\text { Grapefruit extract }\end{array}$ & 401,1 & 320,7 & 0,0 & $240,6 \mathrm{bc}$ \\
\hline Średnia - Mean & $408,7 \mathrm{~A}^{*}$ & 304,4 B & $82,8 \mathrm{C}$ & - \\
\hline
\end{tabular}

Tabela 4. Plon owocników w drugim rzucie po porażeniu przez $M$. perniciosa w zależności od zastosowanego fungicydu [g/0,038 $\left.\mathrm{m}^{2}\right]$ - doświadczenie I

Table 4. Mushroom yield in the second flush after infection with $M$. perniciosa depending on used fungicide [g/0.038 $\mathrm{m}^{2}$ ] - Experiment I

\begin{tabular}{|c|c|c|c|c|}
\hline \multirow{2}{*}{$\begin{array}{l}\text { Wariant } \\
\text { Treatment }\end{array}$} & \multicolumn{3}{|c|}{$\begin{array}{l}\text { Liczba zarodników } / \mathrm{m}^{2} \text { okrywy } \\
\text { Number of conidia } / \mathrm{m}^{2} \text { casing }\end{array}$} & \multirow{2}{*}{$\begin{array}{c}\text { Średnia } \\
\text { Mean }\end{array}$} \\
\hline & 0 & $1,3 \times 10^{6} / \mathrm{m}^{2}$ & $1,3 \times 10^{6} / \mathrm{m}^{2}$ & \\
\hline $\begin{array}{l}\text { Bez fungicydu } \\
\text { Without fungicide }\end{array}$ & $388,8 \mathrm{~A}^{*} \mathrm{a}^{* *}$ & $156,3 \mathrm{Bb}$ & $0,0 \mathrm{Cb}$ & $188,3 \mathrm{~b}$ \\
\hline Prochloraz-Mn & $390,6 \mathrm{Aa}$ & $361,0 \mathrm{Aa}$ & $134,3 \mathrm{Ba}$ & $299,5 \mathrm{a}$ \\
\hline Imazalil & $392,1 \mathrm{Aa}$ & $374,6 \mathrm{Aa}$ & $183,3 \mathrm{Ba}$ & $316,7 \mathrm{a}$ \\
\hline $\begin{array}{l}\text { Ekstrakt } \mathrm{z} \text { drzewa herbacianego } \\
\text { Tea tree extract }\end{array}$ & $388,1 \mathrm{Aa}$ & $168,6 \mathrm{Bb}$ & $0,0 \mathrm{Cb}$ & $185,6 \mathrm{~b}$ \\
\hline $\begin{array}{l}\text { Ekstrakt z grejpfruta } \\
\text { Grapefruit extract }\end{array}$ & 396,2 Aa & $129,3 \mathrm{Bb}$ & $0,0 \mathrm{Cb}$ & $175,2 \mathrm{~b}$ \\
\hline Średnia - Mean & $391,2 \mathrm{~A}$ & $238,0 \mathrm{~B}$ & $63,5 \mathrm{C}$ & - \\
\hline
\end{tabular}

* średnie w rzędach, oznaczone tymi samymi literami, nie różnią się statystycznie przy $\alpha=0,05$ według testu Tukeya - means in rows, followed by the same letters, are not significantly different at $\alpha=0.05$ according to Tukey's test

** średnie w kolumnach, oznaczone tymi samymi literami, nie różnią się statystycznie przy $\alpha=0,05$ według testu Tukeya - means in columns, followed by the same letters, are not significantly different at $\alpha=0.05$ according to Tukey's test

Tabela 5. Plon owocników w pierwszym rzucie po porażeniu przez $M$. perniciosa w zależności od zastosowanego fungicydu $\left[\mathrm{g} / 0,038 \mathrm{~m}^{2}\right]$ - doświadczenie II

Table 5. Mushroom yield in the first flush after infection with M. perniciosa depending on used fungicide $\left[\mathrm{g} / 0.038 \mathrm{~m}^{2}\right]-$ Experiment II

\begin{tabular}{|c|c|c|c|c|}
\hline \multirow{2}{*}{$\begin{array}{l}\text { Wariant } \\
\text { Treatment }\end{array}$} & \multicolumn{3}{|c|}{$\begin{array}{l}\text { Liczba zarodników } / \mathrm{m}^{2} \text { okrywy } \\
\text { Number of conidia } / \mathrm{m}^{2} \text { casing }\end{array}$} & \multirow{2}{*}{$\begin{array}{l}\text { Średnia } \\
\text { Mean }\end{array}$} \\
\hline & 0 & $1,3 \times 10^{6} / \mathrm{m}^{2}$ & $1,3 \times 10^{6} / \mathrm{m}^{2}$ & \\
\hline 1 & 2 & 3 & 4 & 5 \\
\hline $\begin{array}{l}\text { Bez fungicydu } \\
\text { Without fungicide }\end{array}$ & $342,3^{* * *}$ & 233,7 & 120,3 & $232,1 b^{* *}$ \\
\hline Prochloraz-Mn & 337,4 & 326,8 & 246,3 & $303,5 \mathrm{a}$ \\
\hline Imazalil & 339,6 & 316,9 & 245,4 & $300,6 \mathrm{a}$ \\
\hline $\begin{array}{l}\text { Ekstrakt } \mathrm{z} \text { drzewa herbacianego } \\
\text { Tea tree extract }\end{array}$ & 336,6 & 286,2 & 105,7 & $242,8 \mathrm{~b}$ \\
\hline
\end{tabular}




\begin{tabular}{l|c|c|c|c}
\hline \multicolumn{1}{c|}{1} & 2 & 3 & 4 & 5 \\
\hline $\begin{array}{l}\text { Ekstrakt z grejpfruta } \\
\text { Grapefruit extract }\end{array}$ & 346,7 & 282,3 & 184,2 & $271,1 \mathrm{ab}$ \\
\hline Średnia - Mean & $340,5 \mathrm{~A}^{*}$ & $286,7 \mathrm{~B}$ & $158,6 \mathrm{C}$ & - \\
\hline
\end{tabular}

* średnie w rzędach, oznaczone tymi samymi literami, nie różnią się statystycznie przy $\alpha=0,05$ według testu Tukeya - means in rows, followed by the same letters, are not significantly different at $\alpha=0.05$ according to Tukey's test

** średnie w kolumnach, oznaczone tymi samymi literami, nie różnią się statystycznie przy $\alpha=0,05$ według testu Tukeya - means in columns, followed by the same letters, are not significantly different at $\alpha=0.05$ according to Tukey's test

*** brak współdziałania między liczbą zarodników a fungicydami - no interaction between number of conidia and fungicides

Tabela 6. Plon owocników w drugim rzucie po porażeniu przez M. perniciosa w zależności od zastosowanego fungicydu [g/0,038 $\left.\mathrm{m}^{2}\right]$ - doświadczenie II

Table 6. Mushroom yield in the second flush after infection with $M$. perniciosa depending on used fungicide [g/0.038 $\mathrm{m}^{2}$ ] - Experiment II

\begin{tabular}{|c|c|c|c|c|}
\hline \multirow{2}{*}{$\begin{array}{l}\text { Wariant } \\
\text { Treatment }\end{array}$} & \multicolumn{3}{|c|}{$\begin{array}{l}\text { Liczba zarodników } / \mathrm{m}^{2} \text { okrywy } \\
\text { Number of conidia } / \mathrm{m}^{2} \text { casing }\end{array}$} & \multirow{2}{*}{$\begin{array}{c}\text { Średnia } \\
\text { Mean }\end{array}$} \\
\hline & 0 & $1,3 \times 10^{6} / \mathrm{m}^{2}$ & $1,3 \times 10^{6} / \mathrm{m}^{2}$ & \\
\hline $\begin{array}{l}\text { Bez fungicydu } \\
\text { Without fungicide }\end{array}$ & $216,4 \mathrm{~A}^{*} \mathrm{a}^{* *}$ & $145,3 \mathrm{Bc}$ & $0,0 \mathrm{Cb}$ & $120,6 \mathrm{~b}$ \\
\hline Prochloraz-Mn & $227,9 \mathrm{Aa}$ & $222,4 \mathrm{Aab}$ & $193,0 \mathrm{Aa}$ & $214,4 \mathrm{a}$ \\
\hline Imazalil & $220,6 \mathrm{Aa}$ & 213,4 Aabc & $183,0 \mathrm{Aa}$ & 205,7 a \\
\hline $\begin{array}{l}\text { Ekstrakt } \mathrm{z} \text { drzewa herbacianego } \\
\text { Tea tree extract }\end{array}$ & $209,1 \mathrm{Aa}$ & $165,9 \mathrm{Abc}$ & $0,0 \mathrm{Bb}$ & $125,0 \mathrm{~b}$ \\
\hline $\begin{array}{l}\text { Ekstrakt z grejpfruta } \\
\text { Grapefruit extract }\end{array}$ & $217,9 \mathrm{Aa}$ & $159,6 \mathrm{Abc}$ & $0,0 \mathrm{Cb}$ & $125,8 \mathrm{~b}$ \\
\hline Średnia - Mean & $218,4 \mathrm{~A}$ & $181,3 \mathrm{~B}$ & $75,2 \mathrm{C}$ & - \\
\hline
\end{tabular}

* średnie w rzędach, oznaczone tymi samymi literami, nie różnią się statystycznie przy $\alpha=0,05$ według testu Tukeya - means in rows, followed by the same letters, are not significantly different at $\alpha=0.05$ according to Tukey's test

** średnie w kolumnach, oznaczone tymi samymi literami, nie różnią się statystycznie przy $\alpha=0,05$ według testu Tukeya - means in columns, followed by the same letters, are not significantly different at $\alpha=0.05$ according to Tukey's test

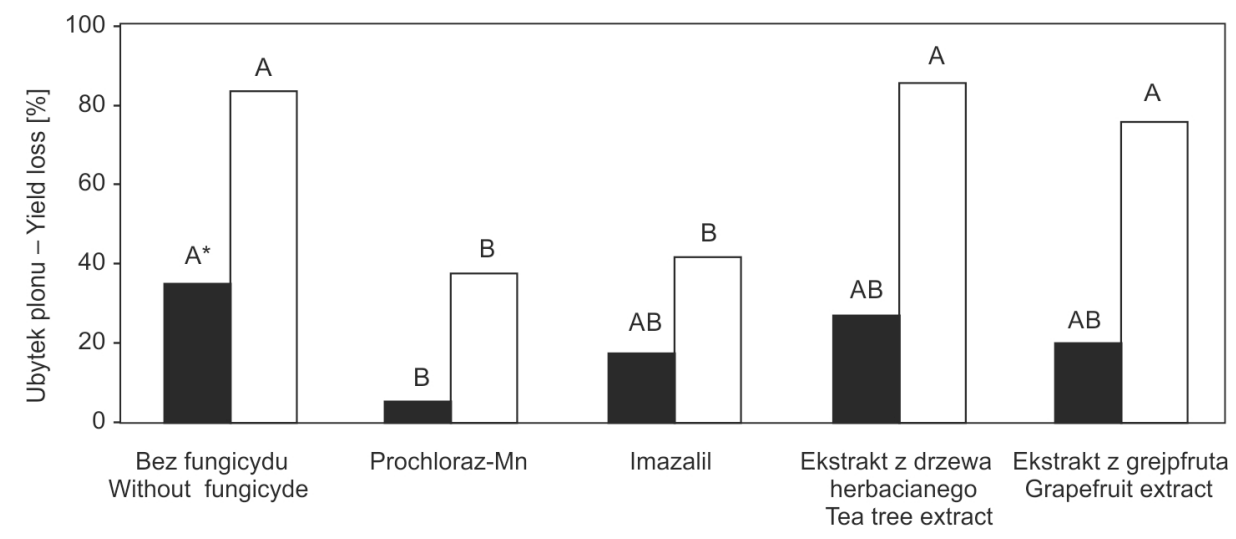

$$
1,3 \times 10^{4} * * \quad \square 1,3 \times 10^{6 * *}
$$

* średnie dla poszczególnych koncentracji, oznaczone tymi samymi literami, nie różnią się statystycznie przy $\alpha=0,05$

- means for particular concentrations, followed by the same letters, are not significantly different at $\alpha=0.05$

** liczba zarodników M. perniciosa - number of $M$. perniciosa spores

Rys. 1. Ubytek plonu owocników w pierwszym rzucie po porażeniu uprawy przez różną liczbę zarodników M. perniciosa i zastosowaniu fungicydów (średnia $\mathrm{z}$ dwóch serii doświadczenia)

Fig. 1. Reduction of mushroom yield in the first flush after infection by various number of $M$. perniciosa spores and used fungicides (average of two series of the experiment)

wynosił 120,3, 105,7 i 184,2 g/0,038 $\mathrm{m}^{2}$, odpowiednio próba kontrolna, $\mathrm{z}$ ekstraktem $\mathrm{z}$ drzewa herbacianego i z grejpfruta (tab. 3, 5). W II rzucie w kombinacjach bez fungicydu oraz ze środkami naturalnymi plonu nie uzyskano w obu doświadczeniach, natomiast plon w próbach z preparatami chemicznymi był porównywalny i wy- 


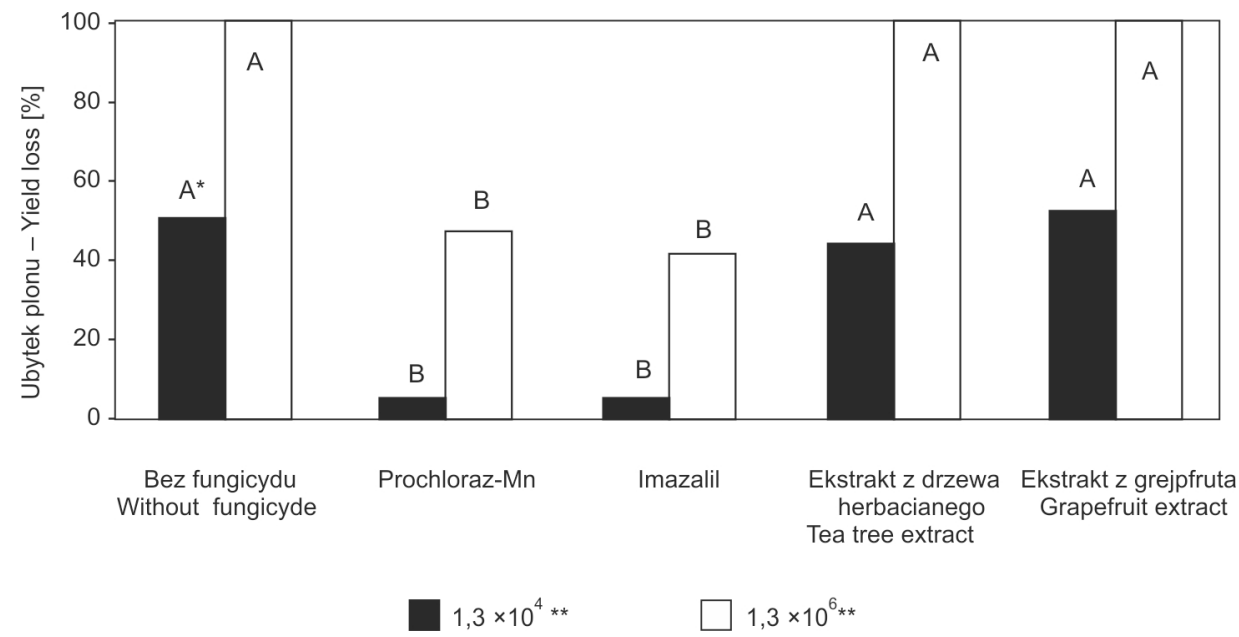

* średnie dla poszczególnych koncentracji, oznaczone tymi samymi literami, nie różnią się statystycznie przy $\alpha=0,05$

- means for particular concentrations, followed by the same letters, are not significantly different at $\alpha=0.05$

** liczba zarodników M. perniciosa - number of M. perniciosa spores

Rys. 2. Ubytek plonu owocników w drugim rzucie po porażeniu uprawy przez różną liczbę zarodników M. perniciosa i zastosowaniu fungicydów (średnia $\mathrm{z}$ dwóch serii doświadczenia)

Fig. 2. Reduction of mushroom yield in the second flush after infection by various number of $M$. perniciosa spores and used fungicides (average of two series of the experiment)

nosił średnio $163,7 \mathrm{~g} / 0,038 \mathrm{~m}^{2}$ dla prochlorazu-Mn i $183,2 \mathrm{~g} / 0,038 \mathrm{~m}^{2}$ dla imazalilu (tab. 4, 6). W II rzucie w obu doświadczeniach wykazano współdziałanie między koncentracjami zarodników a fungicydami (tab. 4, 6), co wskazuje, że na plon owocników miał wpływ dodatek fungicydów chemicznych i różna liczba konidiów. Natomiast w I rzucie nie stwierdzono współdziałania między badanymi czynnikami (tab. 3, 5). Procentowy średni ubytek plonu owocników przy liczbie zarodników $1,3 \times 10^{6} / \mathrm{m}^{2} \mathrm{w}$ I rzucie był porównywalny z rzutem II. W próbach bez fungicydu oraz ze środkami roślinnymi w I rzucie wynosił około $80 \%$, a w II - 100\%. Tak wysoki ubytek plonu spowodowany przez $M$. perniciosa wykazali także Sharma i Kumar (2000). W kombinacjach traktowanych preparatami chemicznymi, tj. $\mathrm{z}$ prochlorazu-Mn i imazalilu, ubytek plonu kształtował się na poziomie $40 \%$ w obu rzutach (rys. 1, 2).

Uzyskane wyniki plonu wskazują na dużą skuteczność ograniczania białej zgnilizny przez badane fungicydy chemiczne $w$ obu rzutach, a także ekstraktu $\mathrm{z}$ grejpfruta w I rzucie przy liczbie zarodników $1,3 \times 10^{4} / \mathrm{m}^{2}$. Skuteczność ekstraktu $\mathrm{z}$ grejpfruta w ograniczaniu rozwoju M. perniciosa została już potwierdzona w badaniach in vitro (Szumigaj-Tarnowska i wsp. 2012). Ponadto w badaniach Górskiego i wsp. (2006) ekstrakt z grejpfruta wyraźnie ograniczał rozwój innego patogena pieczarki, tj. Trichoderma harzianum. Może to wskazywać na możliwość wykorzystania tego ekstraktu w ochronie pieczarki przed chorobami grzybowymi.

Wrażliwość $M$. perniciosa na prochloraz-Mn była potwierdzana wielokrotnie (Fletcher i wsp. 1983; Potoćnik i wsp. 2008; Gea i wsp. 2010). Badania wykazują, że związek ten jest ciągle skutecznym fungicydem ograniczającym rozwój białej zgnilizny. Wysoką skuteczność imazalilu w ochronie pieczarki przed chorobą daktylium wykazali Ślusarski i wsp. (2012b). W prezentowanych badaniach porównywalną skuteczność imazalilu do prochlorazu-Mn można tłumaczyć stosunkowo jego niską dawką $\left(0,6 \mathrm{~g} / \mathrm{m}^{2}\right)$, podczas gdy w badaniach Ślusarskiego i wsp. (2012b) skuteczność imazalilu w dawce $1,2 \mathrm{~g} / \mathrm{m}^{2}$ była istotnie wyższa niż prochlorazu-Mn. Należy zaznaczyć, że zawartość imazalilu w owocnikach nie przekraczała dopuszczalnego poziomu tej substancji w pieczarkach (Ślusarski i wsp. 2012b). Imazalil jest również skuteczny w ograniczaniu rozwoju, odpornych na związki benzymidazolowe, agresywnych grzybów w uprawie pieczarki z rodzaju Trichoderma (Romaine i wsp. 2008). Uzyskane wyniki potwierdzają zasadność prowadzonych badań oraz ich kontynuowanie w zakresie przydatności nowych preparatów w ochronie pieczarki przed chorobami grzybowymi.

\section{Wnioski / Conclusions}

1. Rozwój białej zgnilizny pieczarki był skutecznie hamowany przez preparaty Sporgon 50 WP (prochlorazMn) oraz Fungazil 100 SL (imazalil) w I i II rzucie owocników.

2. Preparat naturalny Grevit $200 \mathrm{SL}$ (ekstrakt z grejpfruta) ograniczył rozwój choroby w I rzucie przy liczbie zarodników $1,3 \times 10^{4} / \mathrm{m}^{2}$.

3. Preparat Timorex Gold 24 EC (ekstrakt $\mathrm{z}$ drzewa herbacianego) nie wykazał skuteczności w ochronie pieczarki przed białą zgnilizną.

Praca wykonana w ramach projektu własnego nr NN 310733140 finansowanego ze środków Narodowego Centrum Nauki w latach 2011-2014. 


\section{Literatura / References}

Fletcher J.T., Drakes G.D., Talent C.J.W. 1975. The control of wet bubble disease of mushrooms caused by Mycogone perniciosa. Annals of Applied Biology 79 (1): 35-41.

Fletcher J.T., Hims M.J., Hall R.J. 1983. The control of bubble diseases and cobweb disease of mushrooms with prochloraz. Plant Patho$\log 32(2): 123-131$.

Fletcher J.T., Jaffe B., Muthumeenakshi S., Brown A.E., Wright D.M. 1995. Variations in isolates of Mycogone perniciosa and in disease symptoms in Agaricus bisporus. Plant Pathology 44 (1): 130-140.

Gea F.J., Tello J.C., Navarro M.-J. 2010. Efficacy and effects on yield of different fungicides for control of wet bubble disease of mushroom caused by the mycoparasite Mycogone perniciosa. Crop Protection 29 (9): 1021-1025.

Górski R., Frużyńska-Jóźwiak D., Andrzejak R., Sobieralski K., Siwulski M. 2006. The effect of selected preparations on in vitro growth of Trichoderma harzianum and Trichoderma atroviride found in garden mushroom (Agaricus bisporus) crop. Phytopathologia Polonica 42: 29-35.

Kouser S., Shah S. 2013. Isolation and identification of Mycogone perniciosa, causing wet bubble disease in Agaricus bisporus cultivation in Kashmir. African Journal of Agricultural Research 8 (38): 4804-4809.

Potoćnik I., Milijaševic S., Rekanović E., Todorović B., Stepanović M. 2008. Sensitivity of Verticillium fungicola var. fungicola, Mycogone perniciosa and Cladobotryum spp. to fungicides in Serbia. p. 615-627. In: Procceding of the 17th Congress of the International Society for Mushroom Science "Science and Cultivation of Edible and Medicinal Fungi: Mushroom Science XVII". South Africa, Cape Town, 20-24 May 2008, 913 pp.

Romaine C.P., Royse D.J., Schlagnhaufer C. 2008. Emergence of benzimidazole-resistant green mould, Trichoderma aggressivum, on cultivated Agaricus bisporus in North America. Mushroom Science 17: 510-523.

Sharma S.R., Kumar S. 2000. Studies on wet bubble disease of white button mushroom (Agaricus bisporus) caused by Mycogone perniciosa. Mushroom Science 15: 569-575.

Szumigaj-Tarnowska J., Szczechura W., Uliński Z., Ślusarski Cz., Staniaszek M. 2013. Characterization of pathogenic isolates of Mycogone perniciosa derived from polish mushroom houses. 5th Congress of European Microbiologists. Germany, Leipzig, 21-25 July 2013, Program Book, 221 pp.

Szumigaj-Tarnowska J., Uliński Z., Ślusarski Cz. 2012. Ocena skuteczności preparatów biologicznych w ochronie pieczarki przed chorobami grzybowymi. [Assessment of effectiveness of biological agents in the control of fungal diseases of the white button mushrooms]. Progress in Plant Protection/Postępy w Ochronie Roślin 52 (4): 963-968.

Ślusarski Cz., Uliński Z., Szumigaj-Tarnowska J. 2012a. Ocena występowania chorób i stanu sanitarnego w polskich pieczarkarniach. [A survey of the sanitary conditions and the occurrence of infectious diseases on Polish mushroom farms]. Progress in Plant Protection/Postępy w Ochronie Roślin 52 (4): 1052-1057.

Ślusarski Cz., Uliński Z., Szumigaj-Tarnowska J., Miszczak A. 2012b. Wstępna ocena przydatności nowych środków do ochrony pieczarki dwuzarodnikowej przed chorobami. [Preliminary appraisal of the new preparations for protection of the white button mushroom against fungal diseases]. Progress in Plant Protection/Postępy w Ochronie Roślin 52 (4): 1058-1063. 